\title{
Xinjiang in 2013: problems and prospects
}

Colin Mackerras ${ }^{1}$

Department of International Business and Asian Studies, Griffith University, Australia

Abstract: Several major disturbances in Xinjiang in China's northwest in 2013 have further exacerbated already tense ethnic relations between the Han Chinese and the main minority in Xinjiang, the Uighurs, who are Turkic and Muslim. The Chinese state blames terrorism but most Western journalists remain sceptical. China's response has also included befriending countries further west, including Turkey. The outlook is not good for ethnic harmony, but the region is likely to develop economically and the prospects for independence or quasiindependence from China are very poor.

Keywords: Xinjiang, China, Uighurs, ethnic disharmony, Turkey

The Xinjiang Uighur Autonomous Region lies in China's far north-west, and is rich in oil, gas, cotton and other resources. Multiethnic in nature, its population includes, among others, the Han, who are China's dominant ethnic group, and several Muslim minorities, including the Chinese-speaking Hui and four Turkic ethnic groups, most prominently the Uighurs, who are very close culturally to the Uzbeks of Uzbekistan. The 2010 census had the total Xinjiang population at 21,813,334, of whom 10.09 million or 46.24 per cent were Uighurs, and 8.75 million or 40.1 per cent were Han, the remainder belonging to other ethnic groups. The same census showed the Han at 91.5 per cent of China's total mainland population.

Since major rioting in the Xinjiang capital Ürümqi in July 2009, there have been continuing disturbances in various parts of the Autonomous Region. Although these are at a considerably lower level than in 2009, they have been quite serious enough to engender worries about ethnic relations, especially between the Uighurs and the Han Chinese. In 2013, particularly serious incidents occurred on 24 April in Bachu outside Kashgar, in several separate villages in Lukqun Township near Turpan on 26 June, in Hanerik in Hotan Prefecture two days later and in August in Kargilik (Yecheng in Chinese) in Kashgar Prefecture. Official accounts presented these incidents as attacks against police stations and other state institutions, and as clashes between rioters and police, with police being among thsoe suffering casualties. On 20 June Chinese legal media told of criminals who had tried to spread ethnic hatred and terrorism, including audio-files that encouraged jihad and extremist religious views through the Internet and by mobile telephone.

\footnotetext{
'Email: c.mackerras@griffith.edu.au.
} 
An incident that got a good deal of publicity was the killing of the distinguished Muslim seventy-four-year-old imam Abdurehim Daomalla by his own people in August 2013 after returning home from leading evening prayers at Turpan's Kazihan Mosque, the most important in the city for Uighurs. Abdurehim was deputy chairman of Turpan city's government-affiliated Islamic Association. The reason for the murder was that Abdurehim had sided with the government, especially over the June violence in Lukqun, accusing the perpetrators of being terrorists. The father of eight children, he was known for his ability to find solutions to disputes and ease tensions. ${ }^{2}$

Official response to the violence of these various incidents has changed from earlier years in that it no longer puts the blame on a particular organization, the East Turkestan Islamic Movement. However, the government and media do continue to blame separatism, terrorism and religious extremism for fanning social instability in Xinjiang, including hatreds in ethnic relations. Just after the Lukqun incidents, Xi Jinping met with members of the Standing Committee of the Politburo, and in particular with the member charged with ethnic affairs $\mathrm{Yu}$ Zhengsheng, and announced that they would step up crackdown on terrorists. According to a report that emerged from the meeting, which cited a summary by $\mathrm{Yu}$, 'ethnic separatist forces at home and abroad continue to intensify their activities, and deep-seated problems harming social stability in Xinjiang remain fundamentally unsolved. ${ }^{3}$

Many Western observers see the violence more as a reaction to Chinese repression and lack of cultural and religious freedom than as due to terrorism. They claim that police heavyhandedly suppress such minor matters as protests against the arrest of religious leaders over trivial issues. One even argues that, though there may be Uighur hatred towards the Chinese state, terrorism is simply a 'phantom' created by the Chinese state for political purposes. His conclusion from on-the-spot investigation in Hanerik the day after the disturbances of late June 2013 is stark: 'There are no terrorists in Xinjiang'.

However, I argue that terrorism is anything but a phantom in Xinjiang. It is very real and the Chinese state is right to oppose it. It is not only official Chinese sources that refer to Uighur individuals and groups with both the wish and the ability to organize violent action against the Chinese state and individuals. Nick Holdstock, an Englishman who taught in Yili records meeting a man who claimed to have helped organize the July protests in 2009 and stated directly that he wanted a perfect bomb that could kill 1,000 Chinese, and that would

\footnotetext{
' Ponnudurai, 'Imam Stabbed to Death After Supporting Crackdown Against Uyghurs'. 'Buckley, 'Violence in Restive Chinese Region Prompts Crackdown'.

'See an example of this view in Kitto, 'Phantom Enemies'.
} 
make the rest leave Xinjiang. ${ }^{5}$ Although it has good cause to fear terrorism, the Chinese state tends to overreact and to see terrorism even where it does not exist. The reason is because it feels it needs to be ultra-cautious when it sees signs of activity that can be interpreted as terrorist. So if the police or other state organs see manifestations of Uighur culture and Islam that look as if they could be potentially terrorist, they are apt tread on them unnecessarily. That has the effect of exacerbating resentment.

One of the most important of Chinese responses to the ethnic tensions has been to try and speed up economic development, even at the risk of undermining Uighur culture. The city of Kashgar, which is Central Asian and Muslim rather than Chinese in atmosphere, became a Special Economic Zone in 2010. Large sections of the Old City have been destroyed and inhabitants moved to more modern apartment buildings. Although the authorities intend to rebuild some of the old quarter in Uighur style, according to informants I met during a visit there in 2010, there are also plans to expand the number of tall buildings that will alter the atmosphere of the city very directly. Such economic development is not in my opinion designed to undermine Uighur culture, but it is likely to have that effect.

Xinjiang is also interwoven with China's foreign relations, especially in Central Asia, with its important Turkic populations and cultures. China's relations with Central Asian countries have expanded greatly in recent years, to the point where they now occupy a major place on China's priority list. In September 2013, President Xi Jinping made a very high-profile visit to the region, and 'a staggering array of deals worth dozens of billions of dollars were signed' ${ }^{6}$ China regards the region as a source of energy and gas and oil pipelines have opened, with more planned. Such developments are aimed more at China as a whole than at Xinjiang specifically, but the region is undoubtedly affected. China shares joint concern with Central Asian countries over potential Islamist and separatist terrorism.

Another country of particular relevance is Turkey, important because the Uighurs are Turkic ethnically and many of the diaspora have taken up residence there. At the time of the July 5, 2009 riots, the Islamist Turkish Prime Minister Recep Tayyip Erdogan immediately commented that the incident was a kind of genocide. However, he soon withdrew from this position, and in April 2012 even made a historic visit to China, beginning in Ürümqi. This suggested a fundamental improvement in bilateral relations, both in economic and strategic terms, and signalled effective agreement that Xinjiang 'could be a bridge and not a point of

\footnotetext{
${ }^{5}$ Holdstock, The Tree that Bleeds, pp. 344-47.

${ }^{6}$ Horta, 'Central Asia: China Opens a New Silk Road'.
} 
friction between the Chinese and the Turkic worlds'. In 2013, Turkey even put in an order for a Chinese missile defence system worth $\$ 4$ billion, the first time a Chinese supplier had won so important a sale from a member of NATO (the North Atlantic Treaty Organisation).

James Palmer is correct in his assessment of late September 2013 that 'Today, UighurHan ethnic relations are the most bitter in China', tenser and worse even than those between Tibetans and Han. ${ }^{8}$ Although the great majority of Uighurs desire peace and harmony in Xinjiang, there are a few who actively want to stir the pot for their own political gain. Such people regarded the July 2009 riots as 'a good thing', because they made Chinese respect the Uighurs or, as one Uighur told Nick Holdstock: 'They are scared of us. They have seen our strength. ${ }^{9}$ It seems to me that, in 2013, a few people in Xinjiang, mainly Uighurs, are actively trying to worsen Han-Uighur relations because they see this as a way of working towards independence or quasi-independence for Xinjiang. They have little hope of success, because the Chinese state is much too powerful and they do not have nearly enough support either within China or outside. Their most likely road to success would be the collapse of the Chinese Communist Party and the Chinese state, but that is unlikely at present and even a successor regime would not necessarily give them what they want.

Meanwhile, Chinese reaction is to tread heavily on any signs of active separatism/terrorism and to pursue modernization and economic development as quickly and thoroughly as possible. The state does that both through domestic policies and through its relationships with countries to the west. Although there can be severe disadvantages to economic development in the form of the loss of ethnic cultural identity, not to pursue development would be tantamount to leaving the area poor, and would probably arouse even more resentment in the long term. Of course it is possible and desirable for the Chinese state to pursue development and practise greater sensitivity and tolerance towards ethnic cultures. My experience suggests that many well-meaning Chinese and others are trying to do just that. However, attempts to stir up violence against the state makes tolerance more difficult and hatred much easier.

So in my view we are set for a period of very tense ethnic relations in Xinjiang, especially between Uighur and Han. It will probably get worse in the near term, and the July 2009 riots did a great deal to exacerbate already existing hatreds. However, if economic development continues to succeed, if attempts at disruption fail and diminish, it is possible that,

\footnotetext{
Gosset, 'The Significance of Sino-Turkish Relations'.

${ }^{8}$ Palmer, 'The Strangers: Blood and Fear in Xinjiang'.

'Holdstock, The Tree that Bleeds, p. 345.
} 
though it will never disappear, tension will gradually lessen. Given the present trends and overall situation, significant improvement will take at least a generation, if it happens at all.

\section{References}

Buckley, Chris. 'Violence in Restive Chinese Region Prompts Crackdown'. New York Times, June 29, 2013. http://www.nytimes.com/2013/06/30/world/asia/china-orders-securitycrackdown-after-riots-in-restive-region.html?_r=0) (accessed October 17, 2013).

Gosset, David. 'The Significance of Sino-Turkish Relations'. The Huffington Post, August 28, 2013. http://www.huffingtonpost.com/david-gosset/the-significance-of-thes_b_3783780.html (accessed October 20, 2013).

Holdstock, Nick. The Tree that Bleeds, A Uighur Town on the Edge. Edinburgh: Luath Press, 2011.

Horta, Loro. 'Central Asia: China Opens a New Silk Road'. RSIS Commentaries 189 (October 9, 2013). Published by RSIS Centre for Non-Traditional Security Studies, National University of Singapore.

Kitto, Mark. 'Phantom Enemies'. Prospect, August 25, 2013. http://www.prospectmagazine.co.uk/magazine/phantom-enemies-mark-kitto-hetianxinjiang-uighurs-china/ (accessed October 19, 2013).

Palmer, James. 'The Strangers: Blood and Fear in Xinjiang'. South China Morning Post, 27 September 27, 2013. http://www.scmp.com/news/chinainsider/article/1318900/strangers-blood-and-fear-xinjiang (accessed October 19, 2013).

Ponnudurai, Parameswaran, based on reports by Shohret Hoshur. 'Imam Stabbed to Death After Supporting Crackdown Against Uyghurs'. Radio Free Asia, August 16, 2013. http://www.rfa.org/english/news/uyghur/shootout-08252013134303.html (accessed October 16, 2013). 